\title{
PENGARUH PEMBERIAN PUPUK KOTORAN AYAM DAN UREA TERHADAP PERTUMBUHAN DAN HASIL TANAMAN BAWANG DAUN PADA TANAH GAMBUT PEDALAMAN
}

\author{
(Effect of Chicken Manure Fertilizer and Urea on Plant Growth and Yield Leaf Onion \\ (Allium fistulosum L.) in the Inland Peat Soil)
}

\section{Fredy Agus Saputra Pantie, Titin Apung Atikah dan Lusia Widiastuti}

\author{
Jurusan Budidaya Pertanian Fakultas Pertanian Universitas Palangka Raya \\ Kampus UPR Tunjung Nyaho, Jl. Yos Sudarso, Palangka, Jekan Raya, \\ Kota Palangka Raya, Kalimantan Tengah \\ e-mail : titinapungatikah@ymail.com
}

\begin{abstract}
The purpose of this study was to determine the effect of chicken manure and urea on the growth and yield of onion leaves on inland peat soil. The design used was a Completely Randomized Design (CRD) factorial with two treatment factors. The first factor is that chicken manure fertilizer application consists of 4 levels, namely: 0, 5, 10 and 15 tons/ha, and the second factor is the provision of urea that consists of 3 levels, namely: 0, 125 and $250 \mathrm{~kg} / \mathrm{ha}$. The variables measured were plant height and fresh weight of the leaves of onion plants. The results showed that the interaction between chicken manure and urea fertilizer had no significant effect on all variables observed at all ages observed. Single factor giving 15 tons/ha of chicken manure fertilizer showed growth and better results on the average variable plant height and fresh weight of the leaves of onion plants in inland peat soil. Single factor giving of urea 250 $\mathrm{kg} / \mathrm{ha}$ showed growth and better results on the average variable plant height and fresh weight of onion plants in inland peat soil.
\end{abstract}

Keywords: chicken manure, urea, Allium fistulosum L., inland peat soil

\begin{abstract}
Abstrak
Tujuan penelitian ini untuk mengetahui pengaruh pemberian pupuk kotoran ayam dan urea terhadap pertumbuhan dan hasil tanaman bawang daun pada tanah gambut pedalaman. Rancangan yang digunakan adalah Rancangan Acak Lengkap (RAL) faktorial dengan dua faktor perlakuan. Faktor pertama adalah pemberian pupuk kotoran ayam yang terdiri dari 4 taraf, yaitu : $0,5,10$ dan 15 ton/ha, dan faktor kedua adalah pemberian urea yang terdiri dari 3 taraf, yaitu: 0,125 dan $250 \mathrm{~kg} / \mathrm{ha}$. Variabel yang diamati adalah tinggi tanaman dan berat segar tanaman.

Hasil penelitian menunjukkan bahwa interaksi antara pupuk kotoran ayam dan urea tidak berpengaruh nyata terhadap semua variabel pengamatan pada semua umur pengamatan. Faktor tunggal pemberian kotoran ayam 15 ton/ha menunjukkan pertumbuhan dan hasil yang lebih baik terhadap variabel rata-rata tinggi tanaman dan berat segar tanaman bawang daun pada tanah gambut pedalaman. Faktor tunggal pemberian urea $250 \mathrm{~kg} / \mathrm{ha}$ menunjukkan pertumbuhan dan hasil yang lebih baik terhadap variabel rata-rata tinggi tanaman dan berat segar tanaman bawang daun pada tanah gambut pedalaman.
\end{abstract}

Kata kunci : kotoran ayam, urea, Allium fistulosum L., gambut pedalaman

\section{PENDAHULUAN}

Bawang daun merupakan salah satu jenis sayuran daun yang bermanfaat sebagai bumbu dapur dan pencampur sayur-mayur yang populer di seluruh dunia termasuk di Indonesia.
Tanaman bawang daun ini diduga tanaman yang berasal dari kawasan Asia Tenggara, kemudian meluas ditanam di berbagai negara yang beriklim tropis maupun sub-tropis (Rukmana, 1995). 
Tanaman ini di Indonesia sudah ditanam sejak lama bersamaan dengan lintas perdagangan jenis sayuran komersil lainnya. Daerah pusat penyebaran bawang daun semula terkonsentrasi di dataran tinggi yang berhawa sejuk seperti Cipanas dan Pacet, Lembang, dan Malang. Perkembangan selanjutnya bawang daun meluas ke berbagai wilayah di seluruh nusantara yang ditanam di dataran tinggi maupun di dataran rendah (Rukmana, 1995).

Produktivitas nasional tanaman bawang daun pada tahun 2009 mencapai 10,24 ton/ha dan pada tahun 2010 mencapai 9,40 ton/ha, apabila dibandingkan dengan produktivitas di Kalimantan Tengah pada tahun 2009 adalah 3,61 ton/ha dan pada tahun 2010 adalah 3,09 ton/ha, maka produktivitas tanaman bawang daun di Kalimantan Tengah masih jauh lebih rendah dibandingkan produktivitas nasional (BPS Kalimantan Tengah, 2011).

Produksi tanaman bawang daun di Kota Palangka Raya pada tahun 2009 adalah 8.806 kuintal dan pada tahun 2010 sebesar 7.834 kuintal. Produksi tanaman bawang daun yang rendah di Kota Palangka Raya disebabkan karena kondisi lahan gambut yang memiliki kesuburan tanah lebih rendah (BPS Kalimantan Tengah, 2011).

Luas lahan gambut di Kalimantan Tengah adalah $2.280 .789,70$ ha atau $14,44 \%$ dari total luas provinsi (BPS Kalteng, 2008). Ciri menonjol dari gambut pedalaman Kalimantan Tengah adalah gambut ombrogen, artinya gambut yang tergolong dalam dan tingkat kesuburan yang sangat rendah, kapasitas tukar kation sangat tinggi dengan kejenuhan basa yang sangat rendah sehingga menyebabkan kation $\mathrm{K}, \mathrm{Ca}$, dan $\mathrm{Mg}$ sukar tersedia bagi tanaman (Halim, 1995).

Gambut memiliki berat volume yang rendah, kemasaman rendah, sifat kering yang tidak balik, kejenuhan basa yang rendah dan miskin unsur hara mikro (Hardjowigeno, 1997), sedangkan Soepardi (1983) menyatakan bahwa kemasaman yang tinggi dan kejenuhan basa yang rendah menyebabkan ketersediaan $\mathrm{N}$ dan $\mathrm{P}$ rendah, meskipun kadarnya tergolong tinggi, namun tidak mencukupi kebutuhan tanaman. Unsur $\mathrm{N}$ dan $\mathrm{P}$ kebanyakan dijumpai dalam bentuk organik kompleks.

Usaha alternatif yang dapat dilakukan untuk mengatasi ketersediaan unsur hara yang sangat rendah adalah dengan pemberian bahan organik yaitu dengan pupuk kotoran ayam. Selain itu penambahan pupuk anorganik seperti urea dapat pula dilakukan untuk mencukupi dan melengkapi unsur hara yang telah ada.

Pupuk kandang banyak digunakan sebagai sumber bahan organik tanah yang berdampak sangat baik bagi pertumbuhan tanaman karena dapat menambahkan unsur hara dan memperbaiki sifat fisik tanah (Hardjowigeno, 1992).

Urea dengan rumus kimia $\mathrm{CO}\left(\mathrm{NH}_{2}\right)_{2}$ adalah pupuk kimia yang mengandung nitrogen (N) berkadar tinggi. Unsur nitrogen merupakan zat hara yang sangat diperlukan tanaman, pada umumnya untuk pembentukan atau pertumbuhan bagian-bagian vegetatif tanaman yaitu daun, batang dan akar, tetapi bila terlalu 
banyak unsur nitrogen itu sendiri dapat menghambat pembungaan dan pembuahan pada tanaman (Sutedjo, 2002).

Bertolak dari latar belakang yang telah diuraikan di atas maka kiranya perlu dilakukan penelitian mengenai pengaruh pemberian pupuk kotoran ayam dan urea terhadap pertumbuhan dan hasil tanaman bawang daun pada tanah gambut pedalaman.

\section{METODOLOGI}

Penelitian ini dilaksanakan dalam rumah plastik di Kebun Percobaan Jurusan Budidaya Pertanian, Fakultas Pertanian Universitas Palangka Raya. Bahan penelitian yang digunakan berupa benih bawang daun Varietas Semprong, tanah gambut pedalaman, pupuk kotoran ayam, urea, kapur dolomit, dan polybag ukuran $30 \times 30 \mathrm{~cm}$. Alat penelitian yang digunakan berupa meteran, timbangan, cangkul, parang, garu tanah, hand sprayer, plastik, kasa, kamera, gembor, dan alat tulis.

Penelitian ini menggunakan Rancangan Acak Lengkap (RAL) faktorial, yang terdiri dari 2 faktor perlakuan. Faktor pertama adalah pemberian pupuk kandang ayam (A), yang terdiri dari 4 taraf perlakuan, yaitu : $\mathrm{A}_{0}=$ kontrol atau 0 ton/ha (0 $\mathrm{g} /$ polybag); $\mathrm{A}_{1}=$ pupuk kotoran ayam 5 ton/ha $(100 \mathrm{~g} /$ polybag $) ; \mathrm{A}_{2}=$ pupuk kotoran ayam 10 ton/ha (200 g/polybag); dan $\mathrm{A}_{3}=$ pupuk kotoran ayam 15 ton/ha (300 g/polybag). Faktor kedua adalah pemberian Urea (U) yang terdiri dari 3 taraf perlakuan, yaitu : $\mathrm{U}_{0}=$ kontrol atau $0 \mathrm{~kg} / \mathrm{ha}(0 \mathrm{~g} /$ polybag$) ; \mathrm{U}_{1}=$ urea $125 \mathrm{~kg} / \mathrm{ha}$
$(2,5 \mathrm{~g} /$ polybag$)$ dan $\mathrm{U}_{2}=$ urea $250 \mathrm{~kg} / \mathrm{ha}$ (5 g/polybag).

Kedua faktor perlakuan tersebut dikombinasikan dan diperoleh sebanyak 12 (dua belas) kombinasi perlakuan. Sedangkan variabel yang diamati adalah tinggi tanaman dan berat segar tanaman.

\section{HASIL DAN PEMBAHASAN}

\section{Tinggi Tanaman}

Hasil analisis ragam tinggi tanaman bawang daun umur 14, 21, 28 dan 35 hari setelah tanam (hst) menunjukkan bahwa interaksi pemberian pupuk kotoran ayam dan urea tidak berpengaruh nyata terhadap tinggi tanaman bawang daun pada semua umur pengamatan. Faktor tunggal pemberian pupuk kotoran ayam serta pemberian urea masingmasing menunjukkan pengaruh nyata terhadap tinggi tanaman bawang daun pada umur 28 dan 35 hst. Rata-rata pengaruh pemberian pupuk kotoran ayam dan urea terhadap pertumbuhan tinggi tanaman bawang daun disajikan pada Tabel 1.

Berdasarkan Tabel 1, diketahui bahwa dari faktor tunggal pemberian pupuk kotoran ayam dan pupuk urea menunjukkan perbedaan yang nyata pada umur 28 dan 35 hst, terjadi peningkatan rata-rata tinggi tanaman bawang daun yang lebih baik. Faktor tunggal pemberian pupuk kotoran ayam dosis 15 ton/ha $\left(\mathrm{A}_{3}\right)$ pada umur 35 hst dengan rata-rata 32,60 cm/tanaman yang menunjukkan perbedaan yang nyata dengan tanpa pemberian perlakuan (kontrol) 
Tabel 1. Rata-rata tinggi tanaman bawang daun (cm) umur 14, 21, 28 dan 35 hst

\begin{tabular}{ccccc}
\hline Perlakuan & \multicolumn{4}{c}{ Tinggi Tanaman $(\mathbf{c m}) /$ umur (hst) } \\
\cline { 2 - 5 } & $\mathbf{1 4}$ & $\mathbf{2 1}$ & $\mathbf{2 8}$ & $\mathbf{3 5}$ \\
\hline Pupuk Kotoran Ayam (A) : & & & & \\
$\mathrm{A}_{0}$ (kontrol) & 12,40 & 17,99 & $28,28 \mathrm{a}$ & $30,48 \mathrm{a}$ \\
$\mathrm{A}_{1}(5$ ton/ha) & 12,43 & 18,22 & $28,52 \mathrm{ab}$ & $30,71 \mathrm{ab}$ \\
$\mathrm{A}_{2}(10$ ton/ha) & 12,44 & 18,26 & $29,63 \mathrm{ab}$ & $31,72 \mathrm{ab}$ \\
$\mathrm{A}_{3}(15$ ton/ha) & 12,93 & 19,26 & $30,54 \mathrm{~b}$ & $32,60 \mathrm{~b}$ \\
\hline BNJ 5\% & - & - & 2,22 & 2,11 \\
\hline Urea $(\mathrm{U}):$ & & & & \\
$\mathrm{U}_{0}(\mathrm{kontrol})$ & 12,08 & 17,82 & $28,04 \mathrm{a}$ & $30,08 \mathrm{a}$ \\
$\mathrm{U}_{1}(125 \mathrm{~kg} / \mathrm{ha})$ & 12,72 & 18,60 & $29,79 \mathrm{~b}$ & $31,99 \mathrm{~b}$ \\
$\mathrm{U}_{2}(250 \mathrm{~kg} / \mathrm{ha})$ & 12,86 & 19,51 & $29,90 \mathrm{~b}$ & $32,07 \mathrm{~b}$ \\
\hline BNJ 5\% & - & - & 1,74 & 1,65 \\
\hline
\end{tabular}

Keterangan : Nilai rata-rata yang diikuti huruf yang sama pada kolom dan umur yang sama, tidak berbeda nyata menurut uji BNJ 0,05.

dengan rata-rata hanya $30,48 \mathrm{~cm} /$ tanaman, tetapi secara statistik pemberian pupuk kotoran ayam dosis 15 ton/ha $\left(\mathrm{A}_{3}\right)$ tidak berbeda nyata dengan pemberian pupuk kotoran ayam dosis 5 ton/ha $\left(\mathrm{A}_{1}\right)$ dengan rata-rata $30,71 \mathrm{~cm} /$ tanaman dan pupuk kotoran ayam dosis 10 ton/ha $\left(\mathrm{A}_{2}\right)$ dengan rata-rata $31,72 \mathrm{~cm} /$ tanaman.

Faktor tunggal pemberian urea dosis 250 $\mathrm{kg} / \mathrm{ha}\left(\mathrm{U}_{2}\right)$ dengan rata-rata $32,07 \mathrm{~cm} /$ tanaman pada umur 35 hst secara statistik tidak berbeda nyata dengan pemberian urea dosis $125 \mathrm{~kg} / \mathrm{ha}$ $\left(\mathrm{U}_{1}\right)$ dengan rata-rata $31,99 \mathrm{~cm} /$ tanaman, tetapi pemberian urea dosis $250 \mathrm{~kg} / \mathrm{ha} \quad\left(\mathrm{U}_{2}\right)$ ini berbeda nyata dibandingkan tanpa pemberian perlakuan (kontrol) yang rata-rata tinggi tanaman hanya $30,08 \mathrm{~cm} /$ tanaman.

\section{Berat Segar Tanaman}

Hasil analisis ragam berat segar tanaman bawang daun menunjukkan bahwa interaksi pemberian pupuk kotoran ayam dan urea tidak menunjukkan pengaruh nyata terhadap berat segar tanaman bawang daun. Faktor tunggal pemberian pupuk kotoran ayam dan faktor tunggal pemberian urea menunjukkan pengaruh yang sangat nyata terhadap berat segar tanaman bawang daun pada saat pemanenan. Rata-rata pengamatan berat segar tanaman bawang daun disajikan pada Tabel 2.

Berdasarkan Tabel 2, diketahui bahwa dari faktor tunggal pemberian pupuk kotoran ayam dan urea menunjukkan perbedaan yang nyata pada pemanenan, terjadi peningkatan rata-rata berat segar tanaman bawang daun yang lebih baik. Faktor tunggal pemberian pupuk kotoran ayam dosis 15 ton/ha $\left(\mathrm{A}_{3}\right)$ dengan ratarata $18,15 \mathrm{~g} /$ tanaman, menunjukkan perbedaan yang nyata dengan tanpa pemberian perlakuan (kontrol) dengan rata-rata 15,49 g/tanaman dan pemberian pupuk kotoran ayam dosis 5 ton/ha $\left(\mathrm{A}_{1}\right)$ dengan rata-rata $15,99 \mathrm{~g} /$ tanaman, tetapi 
Tabel 2. Rata-rata berat segar tanaman (g)

\begin{tabular}{cc}
\hline Perlakuan & Berat Segar Tanaman (g) \\
\hline Pupuk Kotoran Ayam $(\mathrm{A}):$ & \\
$\mathrm{A}_{0}($ kontrol $)$ & $15,49 \mathrm{a}$ \\
$\mathrm{A}_{1}(5$ ton $/ \mathrm{ha})$ & $15,99 \mathrm{ab}$ \\
$\mathrm{A}_{2}(10$ ton $/ \mathrm{ha})$ & $16,70 \mathrm{abc}$ \\
$\mathrm{A}_{3}(15$ ton $/ \mathrm{ha})$ & $18,15 \mathrm{c}$ \\
\hline BNJ $5 \%$ & 1,71 \\
\hline Urea $(\mathrm{U}):$ & \\
$\mathrm{U}_{0}(\mathrm{kontrol})$ & $15,54 \mathrm{a}$ \\
$\mathrm{U}_{1}(125 \mathrm{~kg} / \mathrm{ha})$ & $16,56 \mathrm{ab}$ \\
$\mathrm{U}_{2}(250 \mathrm{~kg} / \mathrm{ha})$ & $17,65 \mathrm{~b}$ \\
\hline BNJ $5 \%$ & 1,34 \\
\hline
\end{tabular}

Keterangan : Nilai rata-rata yang diikuti huruf yang sama pada kolom yang sama, tidak berbeda nyata menurut uji BNJ 0,05.

secara statistik pemberian pupuk kotoran ayam dosis 15 ton/ha $\left(\mathrm{A}_{3}\right)$ tidak berbeda nyata dengan pemberian pupuk kotoran ayam dosis 10 ton/ha $\left(\mathrm{A}_{2}\right)$ dengan rata-rata $16,70 \mathrm{~g} /$ tanaman.

\section{Pembahasan}

Berdasarkan hasil analisis ragam yang telah disajikan, tidak terjadi interaksi pemberian pupuk kotoran ayam dan urea terhadap semua umur pengamatan tanaman bawang daun, hal ini disebabkan karena urea dapat langsung diserap oleh tanaman, sedangkan pupuk kandang ayam pada awal pertumbuhan masih mengalami proses dekomposisi terlebih dahulu sebelum kandungan $\mathrm{N}$ dapat diserap oleh tanaman, sehingga memberikan pengaruh yang lambat (Mengel and Kirkby, 2001; Marschner, 2002 dalam Mulyati $d k k$., 2007). Hal ini sesuai dengan pendapat Hardjowigeno (2003) bahwa urea merupakan pupuk $\mathrm{N}$ yang mudah larut dan tersedia bagi tanaman, sedangkan pupuk kandang ayam masih mengalami proses perubahan bentuk dari N-organik menjadi $\mathrm{N}$-anorganik melalui proses aminasi, amonifikasi dan nitrifikasi terlebih dahulu. Hal ini juga sesuai yang dengan pendapat Hanafiah (1995), bahwa tidak terjadinya interaksi antara kedua faktor perlakuan tersebut menunjukkan kedua faktor tidak mampu untuk bersinergi (bekerjasama) karena mekanisme kerjanya berbeda atau salah satu faktor tidak berperan secara optimal atau bahkan bersifat antagonis, yaitu saling menekan pengaruh masing-masing faktor perlakuan. Hal ini mengindikasikan bahwa tidak adanya pengaruh sinergisme antara kadar $\mathrm{N}$ dalam kotoran ayam dan $\mathrm{N}$ yang dikandung oleh pupuk urea, sehingga interaksi keduanya menjadi tidak nyata.

Hasil uji BNJ 5\% menunjukkan pengaruh faktor tunggal pemberian pupuk kotoran ayam dosis 15 ton/ha $\left(\mathrm{A}_{3}\right)$ berpengaruh nyata 
terhadap variabel pengamatan rata-rata tinggi tanaman dan pengaruh faktor tunggal pemberian urea dosis $250 \mathrm{~kg} / \mathrm{ha} \quad\left(\mathrm{U}_{2}\right)$ berpengaruh nyata terhadap variabel rata-rata berat segar tanaman bawang daun pada tanah gambut pedalaman, masing-masing faktor tunggal tersebut menunjukkan rata-rata hasil tanaman bawang daun yang lebih baik dibandingkan perlakuan lainnya.

Hasil analisis tanah awal terlihat kadar nitrogen total adalah $0,63 \%$ dan $\mathrm{pH}$ tanah adalah 4,60. Menurut Trisilawati dan Gusmaini (1999, dalam Etika, 2007), bahwa kotoran ayam mengandung 15,06 \% C-organik, 1,52\% $\mathrm{N}, 1,29 \% \mathrm{Ca}, 0,95 \% \mathrm{P}, 0,86 \% \mathrm{~K}, 0,56 \% \mathrm{Mg}$, dan $12 \% \quad \mathrm{C} / \mathrm{N}$. Urea sebanyak $100 \mathrm{~kg}$ mengandung $46 \quad \% \quad \mathrm{~N}$ (Deskripsi Pupuk Anorganik, 2013). Pupuk kotoran ayam dan urea yang diberikan pada tanah gambut pedalaman mampu menyediakan kondisi tanah menjadi lebih baik untuk mendukung pertumbuhan tanaman bawang daun, utamanya dalam menyediakan unsur hara nitrogen. Unsur nitrogen yang dominan terkandung dalam pupuk kotoran ayam dan urea berfungsi dalam meningkatkan pertumbuhan vegetatif tanaman bawang daun. Hal ini sesuai pendapat Elfarisna, $d k k$ (2004) bahwa salah satu cara untuk meningkatkan pertumbuhan vegetatif tanaman adalah dengan pemberian pupuk kotoran ayam dan urea. Menurut Soepardi (1983), bahwa tanah-tanah yang mengandung kation lebih banyak akan memiliki pH lebih tinggi. Selain itu juga pemberian pupuk kotoran ayam dan urea berpengaruh dalam meningkatkan Al-dd dan menaikkan $\mathrm{pH}$, hal ini disebabkan karena bahan organik dari pupuk kotoran ayam dan bahan anorganik dari urea dapat menetralisir sumber kemasaman tanah (Djafaruddin, 1970 dalam Wulandari, 2011).

Peningkatan rata-rata tinggi tanaman dan berat segar tanaman bawang daun diakibatkan peran pupuk kotoran ayam sebagai pupuk organik dan urea sebagai pupuk anorganik yang mampu memperbaiki sifat-sifat fisik, biologi dan kimia di dalam tanah gambut yang menjadi kendala dalam budidaya tanaman, utamanya dalam menyediakan unsur hara bagi tanaman.

Penambahan pupuk kotoran ayam ke dalam tanah selain berfungsi untuk memperbaiki sifat fisik tanah melalui perubahan struktur dan permeabilitas tanah juga dapat memperbaiki kesuburan kimia tanah karena mengandung unsur $\mathrm{N}, \mathrm{P}, \mathrm{K}, \mathrm{Ca}, \mathrm{Mg}$ dan $\mathrm{Cl}$, serta dapat meningkatkan kegiatan mikroorganisme tanah yang berarti juga akan meningkatkan kesuburan tanah (Sutedjo, 1995).

Pupuk kotoran ayam sebagai bahan organik dapat meningkatkan ketersediaan beberapa unsur hara yang diserap oleh tanaman. Syukur dan Indah (2006), mendapatkan bahwa pemberian pupuk kotoran ayam dapat meningkatkan $\mathrm{pH}$ tanah. Walaupun kandungan hara organik relatif rendah, tetapi perombakannya relatif cepat terutama di daerah tropik. Pemberian pupuk kandang berperan sebagai bahan organik tanah secara langsung dapat berfungsi sebagai sumber unsur hara, terutama $\mathrm{N}, \mathrm{S}$ dan sebagian $\mathrm{P}$, serta unsur mikro. Secara tidak langsung bahan organik 
tanah berperan dalam meningkatkan kestabilan agregat, kapasitas menahan air, kapasitas tukar kation (KTK), daya sangga tanah, serta menurunkan serapan $\mathrm{P}$ oleh tanah. Unsur hara nitrogen yang terkandung dalam pupuk urea sangat penting perannya bagi pertumbuhan dan perkembangan tanaman, antara lain: daun tanaman menjadi lebih hijau segar dan banyak mengandung butir hijau daun (klorofil) yang berperan dalam proses fotosintesa, mempercepat pertumbuhan tanaman, menambah kandungan protein tanaman (Marsono dan Lingga, 2002).

Pemberian pupuk kotoran ayam yang diberikan dengan beberapa takaran mampu meningkatkan metabolisme tanaman. Peningkatan ini disebabkan oleh keunggulan pupuk organik dalam hal ini kotoran ayam, karena selain mengandung unsur $\mathrm{N}, \mathrm{P}$ (makro) juga mengandung unsur mikro meskipun dalam jumlah yang rendah. Senyawa-senyawa ini selanjutnya berperan dalam meningkatkan pembentukan senyawa asam-asam amino, protein dan komponen-komponen khlorofil yang menyebabkan proses fotosintesis berlangsung dengan baik, dan pada gilirannya akan meningkatkan fotosintat dalam tubuh tanaman, akibatnya bobot brangkasan kering tanaman juga meningkat (Lakitan, 1993; Taiz and Zeiger, 1998 dalam Mulyati dkk., 2007).

Peranan nitrogen yang terkandung di dalam urea bagi tanaman adalah untuk merangsang pertumbuhan secara keseluruhan khususnya batang, cabang, akar dan daun
(Lingga, 2001), sedangkan menurut Lakitan (2004), nitrogen dalam jaringan tumbuhan merupakan komponen penyusun dari banyak senyawa esensial bagi tanaman misalnya asam-asam amino, karena setiap molekul protein tersusun dari asam-asam amino dan setiap enzim adalah protein, maka nitrogen juga merupakan unsur penyusun protein dan enzim.

Hasil penelitian menunjukkan pada perlakuan faktor tunggal pupuk kotoran ayam pada umur 28 hst berpengaruh nyata dan pada umur 35 hst berpengaruh sangat nyata terhadap rata-rata tinggi tanaman dan berat segar tanaman bawang daun pada saat pemanenan. Demikian pula, perlakuan tunggal urea berpengaruh nyata terhadap variabel ratarata tinggi tanaman maupun berat segar pada umur 28 dan 35 hst. Hal ini membuktikan bahwa tanaman bawang daun merupakan tanaman yang perlu unsur hara khususnya $\mathrm{N}$ dalam jumlah cukup besar selama pertumbuhannya.

Berdasarkan unsur hara yang diperlukan tanaman, nitrogen $(\mathrm{N})$ adalah unsur yang paling utama menentukan pertumbuhan dan hasil tanaman bawang daun. Tersedianya unsur nitrogen yang lebih besar yang terkandung dari urea sangat berperan langsung dalam memacu peningkatan pertumbuhan dan perkembangan tanaman bawang daun. Meningkatnya tinggi tanaman dan berat segar tanaman dapat menjadi indikator meningkatnya pertumbuhan tanaman bawang daun secara keseluruhan. 


\section{SIMPULAN}

Hasil penelitian yang telah dilaksanakan menghasilkan simpulan sebagai berikut :

1. Interaksi antara pupuk kotoran ayam dan urea tidak berpengaruh nyata terhadap semua variabel pengamatan pada semua umur pengamatan.

2. Faktor tunggal pemberian kotoran ayam 15 ton/ha $\left(\mathrm{A}_{3}\right)$ menunjukkan pertumbuhan dan hasil yang lebih baik terhadap ratarata tinggi tanaman dan berat segar tanaman bawang daun pada tanah gambut pedalaman.

3. Faktor tunggal pemberian urea $250 \mathrm{~kg} / \mathrm{ha}$ $\left(\mathrm{U}_{2}\right)$ menunjukkan pertumbuhan dan hasil yang lebih baik terhadap rata-rata tinggi tanaman, dan berat segar tanaman bawang daun pada tanah gambut pedalaman.

\section{DAFTAR PUSTAKA}

Badan Pusat Statistik, 2011. Statistik Tanaman Hortikultura 2009 dan 2010, Badan Pusat Statistik Propinsi Kalimantan Tengah. Palangka Raya.

Deskripsi Pupuk Anorganik, 2013. From : (http://vrimst.blogspot.com/201 Pupuk Urea, Pupuk SP 36). (Verified 17 juli 2013)

Efarisna, Parsan and Sularno. 2004. Pengaruh Pupuk Untuk Meningkatkan Pertumbuhan Vegetatif. Prosiding Seminar Nasional Hortikultura, Bogor, 45 Agustus 2004.

Etika, Y.V. 2007. Pengaruh Pemberian Kompos Kulit Kopi, Kotoran Ayam dan Kombinasinya Terhadap Ketersediaan Unsur $\mathrm{N}, \mathrm{P}$, dan $\mathrm{K}$ Pada Inceptisol. Universitasa Brawijaya. Malang.
Halim. 1985. Upaya Memproduksi Tanah Gambut Pedalaman Kalimantan Tengah. Kasus Bereng Bengkel. Makalah Seminar Kebutuhan dan Pemanfaatan Tanah Gambut di Kalimantan Tengah. Universitas Palangka Raya. Palangka Raya.

Hanafiah, K.A. 1995. Rancangan Percobaan. Rajawali Pers. Jakarta.

Hardjowigeno, S. 1992. Ilmu Tanah. PT. Mediatama Sarana Prakarsa. Jakarta.

Hardjowigeno, S. 1997. Ilmu Tanah. PT. Mediatama Sarana Prakarsa. Jakarta.

Hardjowigeno, S. 2003. Ilmu Tanah. PT. Mediatama Sarana Prakarsa. Jakarta.

Lakitan, 2004. Dasar-dasar Fisiologi Tumbuhan.Raja Grafindo Persada. Jakarta.

Lingga dan Marsono. 2001. Petunjuk Penggunaan Pupuk. Penebar Swadaya. Jakarta.

Marsono dan Lingga, P. 2002. Petunjuk Penggunaan Pupuk. Penebar Swadaya. Jakarta.

Mulyati, R.S. Tejowulan dan V.A. Octarina. 2007. Respon Tanaman Tomat Terhadap Pemberian Pupuk Kandang Ayam dan Urea terhadap Pertumbuhan dan Serapan N. Jurnal Agroteksos Vol. 17 Nomor 1, April 2007.

Soepardi, G. 1983. Sifat dan Ciri Tanah. Departemen Ilmu Tanah IPB. Bogor.

Syukur, A dan Indah, N.M. 2006. Kajian Pengaruh Pemberian Macam Pupuk Organik terhadap Pertumbuhan dan Hasil Tanaman Jahe di Inceptisol, Karanganyar. Jurnal Ilmu Tanah dan Lingkungan Vol 6 (2) 2006. p:124-131 
Wulandari, V. 2011. Pengaruh Pemberian Beberapa Dosis Pupuk Kandang Ayam Terhadap Pertumbuhan dan Hasil Tanaman Rosella (Hibiscus sabdariffa L.) di tanah ultisol. Skripsi. Fakultas Pertanian Universitas Andalas Padang. 